\title{
Rogers suggests interim legislation on DNA research
}

THE draft of a new bill covering both public and private research on recombinant DNA has been produced by Representative Paul G. Rogers in an attempt to break the deadlock on congressional legislation that developed late last autumn.

According to the provisions of the proposed bill, interim legislation would come into effect for a period of two years under which all such research would be required to be covered by guidelines laid down by the National Institutes of Health.

In addition, a commission for the study of research and technology would be set up charged with conducting a study of federal policy regarding activities involving the genetic modification of organisms and viruses. The commission would make a report within two years containing recommendations regarding federal action to be taken to promote, regulate or review such activities.

$\mathrm{Mr}$ Rogers is chairman of the subcommittee on health and the environment of the House Committee on Interstate and Foreign Commerce. Discussion on an earlier bill supported by the sub-committee was not completed by the full committee in the last legislative session, and the delay meant that the bill did not reach the floor of the house.

Under the provisions of the new bill, all those in the process of carrying out experiments involving recombinant DNA or proposing to do so would be required to provide an assurance to the secretary of the Department of Health, Education and Welfare that the work was being carried out in accordance with the NIH guidelines (the present guidelines, which were introduced in 1976, are currently being revised).

Those found to be ignoring the guidelines would be liable to a civil penalty (a fine) and the possible suspension of research funds.

Supporters of the new bill are hoping that by avoiding some of the more controversial aspects of the present debate--such as the problem of the 'prior disclosure' of research results, or the legal protection of employees who provide evidence of infringements-it will bring together house, senate and administration thinking, and have a higher chance of success than last autumn's attempt.

A further controversial issue is whether the federal government should be allowed to pre-empt local legislation. The bill's final position on this is likely to be the outcome of lengthy discussion with members of Congress and the administration.
But even if this approach fails to break the current deadlock, there is still a chance that the administration could develop a regulatory framework for both publicly and privately funded recombinant DNA research through existing legislation, namely section 361 of the Public Health Act.

Although the government had previously stated, following a petition from the Environmental Protection Fund in 1976, that it felt this legislation did not cover DNA research, recent re-examination of previous issues to which the act has been applied has indicated that this may indeed be possible.

Speaking at hearings held in

\section{Tsiolkovskii's dream}

THE link-up of Salyut-6 and Soyuz-26 and 27 marks a further step towards Tsiolkovskii's dream of a permanent orbital space station. Yet, rather strangely, the link-up was not used to effect a change of personnel, but merely to simulate one; the second crew-Vladimir Dzhanibekov and Oleg Makarov-returning to earth only five days after launch, and leaving the veterans-Yurii Romanenko and Georgii Grechko-still in orbit.

Salyut-6, with its two docking bays, represents a new generation of Soviet spacecraft. The docking bays are interchangeable, so that when Soyuz-25 failed to dock and it was suspected that there was some fault in the docking equipment, Soyuz-26, as backup mission, docked in the second bay. Only after Romanenko and Grechko had checked out the first bay was this used for the linkup of Soyuz-27. Although there was no actual change of crew, the returning cosmonauts did change spacecraft, returning to earth aboard Soyuz-26. The launch of the second crew one month to the day after the first may be some indication of the shift-length planned for a fully operational space station; such a station, it is stressed, could save considerably on the time at present spent in warming up and mothballing the station at the beginning and end of singleton missions.

In addition to comforts for the "resident" crew-books, mail, newspapers-and the cherry juice required for the ritual toast-the "relieving" Soyuz-27 carried two temperaturestable "Bioterm-8" containers containing, respectively, the paramecium and proteus cultures for the FrancoSoviet "Cytos" experiment, which studies the effect of space-flight on cell-division. The "visiting" crew also
Washington last November by Senator Adlai Stevenson, Dr Gilbert Omenn of the President's Office of Science and Technology Policy said that the administration had rejected section 361 as being neither appropriate nor sufficient for recombinant DNA research.

However after looking at some of the previous applications more closely, the administration is beginning to have second thoughts, and is now looking closely at ways in which, if congress fails to come up with the appropriate legislation, regulations covering research with recombinant DNA could be implemented under section 361 .

David Dickson

carried out a study of blood circulation, data from which, it is hoped, can be used to develop prophylactic measures to help cosmonauts adapt to weightlessness. Dzhaniberkov, an expert on radioelectronics, checked out the various on-board systems, and all four took part in the mechanical "resonance" experiment to determine the exact strength characteristic of the compound structure.

With mail delivered again to orbit (the first time since the Soyuz $4 / 5$ linkup of 1969), a radiorepair man on call, and (according to veteran cosmonaut Valerii Kubasov) plans for refuelling the correction engines already under discussion, Tsiolkovskii's vision seems perceptibly nearer. Yet in one respect, Salyut-6 would seem to represent a retrograde step. Although, according to Grechko, the work aboard Salyut-6 is more interesting than his previous mission on Salyut-4, since the cosmonauts can now go for spacewalks, nevertheless he misses the "oasis, where we grow plants and peas" of the earlier craft.

Vera Rich

\section{US industry attacks Ames test}

SHORT-TERM bacterial tests for potential carcinogens, such as that developed by Dr Bruce Ames at the University of California, do not predict similar responses in humans, according to the American Industrial Health Council, a New York based lobby group for the US chemical industry.

In comments on legislation covering the industrial use of potential and known carcinogens proposed by the Occupational Safety and Health Administration, the council, whose members include representatives of the 